\title{
INTERNALISASI FILOSOFI TRILOGI PENDIDIKAN KI HADJAR DEWANTARA DALAM PEMAHAMAN PRODUCT KNOWLEDGE SYARIAH
}

\author{
Yohan Bakhtiar \\ Universitas Brawijaya, J1. MT. Haryono 165, Malang \\ Surel: Yohan_bakhtiar@yahoo.co.id
}

\begin{abstract}
Abstrak. Internalisasi Filosofi Trilogi Pendidikan Ki Hadjar Dewantara dalam Pemahaman Product Knowledge Syariah. Tujuan penelitian ini adalah untuk mengimplementasikan nilai-nilai filosofis trilogi pendidikan Ki Hadjar Dewantara dalam membangkitkan kesadaran akan arti pentingnya product knowledge sebagai salah satu aspek non-material dalam perbankan syariah. Metode penelitian yang digunakan untuk internalisasi pemahaman nilai-nilai keIslaman dalam berbisnis yaitu trilogi pendidikan Ki Hadjar Dewantara (Ing Ngarsa Sung Tuladha, Ing Madya Mangun Karsa,Tut Wuri Handayani). Temuan dari penelitian ini menunjukkan bahwa intervensi dapat diterapkan sebagai salah satu tujuan untuk memberikan kesadaran dan perubahan terhadap nilainilai bisnis keuangan Islam yang semula dipersamakan dengan bisnis keuangan konvensional.
\end{abstract}

Abstract. Internalization of Ki Hadjar Dewantara's Education Trilogy Philosophy in Understanding Islamic Product Knowledge. The purpose of this research is to implement values of education-trilogy philosophy by Ki Hadjar Dewantara in raising awareness of the importance product knowledge as one of the non-material aspects in Islamic banking. The method used to internalize the understanding of Islamic values in having a business is education trilogy by Ki Hadjar Dewantara (Ing Ngarsa Sung Tuladha, Ing Madya Mangun Karsa, Tut Wuri Handayani). The finding shows that intervention can be implemented as one of the aims to get awareness and change to the values of Islamic finance business which was originally equalized with the conventional one.

Kata kunci: Internalisasi, Pendidikan, Product Knowledge, Syariah

"Hidup manusia itu pokok pangkalnja ialah berdjoang dan membangun,

tak dengan berhenti-henti.."

(Ki Hadjar Dewantara 1967)

Bisnis, selama ini yang dipandang dan dipahami oleh banyak orang adalah bagaimana menghasilkan keuntungan yang maksimal dengan modal yang seminimal mungkin ${ }^{1}$. Inilah pe-

1 Hal ini sesuai dengan prinsip ekonomi kapitalistik dimana telah menjadi 'kitab suci' yang dipelajari oleh hampir semua mahasiswa, ironisnya bahkan semenjak sekolah dari tingkat dasar, mene-ngah dan akhir (refleksi penulis). mikiran yang mendarah daging dalam setiap benak kebanyakan pebisnis, tidak hanya di negaranegara penganut paham kapitalistik, bahkan di Indonesia dan negara-negara Islam lainnya yang notabene mayoritas penduduknya merupakan kaum muslimin. Cara pandang seperti ini sesuai dengan pemikiran John Mackey dalam artikelnya yang berjudul Conscious Capitalism: Creating a New Paradigm for Business (2007) dan menyatakan bahwa inti dari masalah kapitalisme adalah bisnis saat ini melihat tujuan mereka sebagai maksimalisasi laba dan memperlakukan semua pihak dalam organisasi sebagai sarana untuk mencapai tujuan tersebut. Untuk

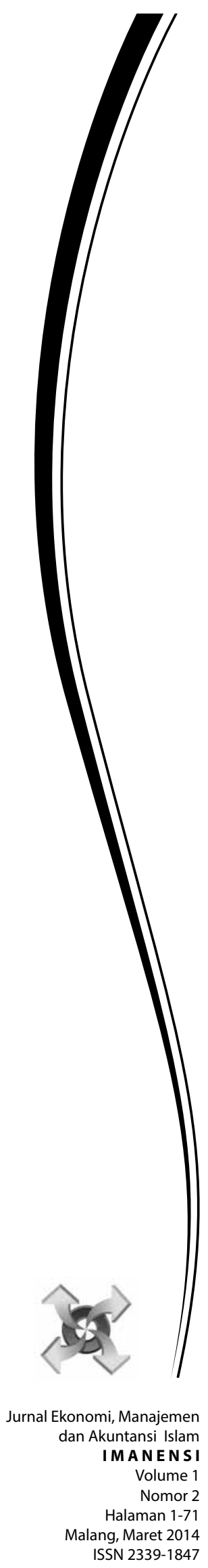


menyikapi dampak hegemoni ${ }^{2}$ kapitalis ini, Khobir (2010) menyatakan suatu pendapat yaitu dengan cara memformulasikan sistem ekonomi yang berlandaskan pada prinsipprinsip ajaran Islam, yaitu kerja sama, tolong menolong, mengakui eksistensi individu tidak secara berlebihan, tidak ada dominasi kelas dan tidak ada pencarian keuntungan yang tidak mengindahkan ketentuan-ketentuan yang berlaku.

Jika berbicara tentang nilai-nilai bisnis Islam, pastilah tidak terlepas dengan etika dimana dimensi etika adalah ranah implementasi dari nilai-nilai tersebut. Etika berbisnis dalam Islam, jika dibandingkan dengan bisnis kaum kapitalistik adalah dapat terlihat dari pendistribusian kekayaan dimana kaum pemodal lebih berorientasi untuk menimbun kekayaannya demi kepentingan pribadi (self interest). Inilah salah satu penyebab terjadinya 'wabah' globalisasi yang semakin berdampak sistemik terhadap berbagai sisi kehidupan. Bahkan (Shonhadji 2013:6) menyebutkan pada tingkat yang lebih ekstrim, globalisasi bermuara pada terjadinya pelebaran kesenjangan sosial dan ekonomi, dan meningkatnya dominasi para pemodal negara-negara kaya terhadap pemilikan faktor-faktor produksi di setiap negara miskin dan berkembang. Lain halnya dalam bisnis Islam, junjungan Nabi Muhammad SAW telah memberikan suri tauladannya dalam menjalankan praktik bisnis syariah yaitu beliau memiliki prinsip jujur, amanah, tepat dalam menimbang, menjauhi gharar, tidak menimbun barang, tidak melakukan $a l-g h a b^{3}$ dan tadlis ${ }^{4}$, dan saling menguntungkan (mutual benefit principle) antara penjual dan pembeli (Saifullah 2011). Dengan demikian, jika mampu mengimplementasikan dengan baik sistem perdagangan yang berbasis pada prinsip ekonomi Islam dapat menjamin terselenggaranya perekonomian dunia yang lebih adil dan membawa kesejahteraan umat manusia sesuai dengan prinsip fundamental Islam yang "rahmatan lil'alamin".

2 Menurut Gramsci (dalam Shonhadji 2013:7), hegemoni bukanlah hubungan dominasi dengan menggunakan kekuasaan, melainkan hubungan persetujuan dengan menggunakan kepemimpinan politik dan ideologis.

3 Artinya al-khada (penipuan), yakni membeli sesuatu dengan harga yang lebih tinggi atau lebih rendah dari harga rata-rata.

4 Penipuan yang dilakukan oleh pihak penjual atau pembeli dengan cara menyembunyikan kecacatan ketika terjadi transaksi.
Dunia bisnis Islam, salah satunya yang mempunyai perkembangan paling signifikan adalah perbankan syariah dimana sistem bunga (riba) yang diterapkan oleh perbankan konvensional diharamkan dan diganti dengan sistem bagi hasil (profit sharing). Hal ini sesuai dengan kandungan surat Al Baqarah ayat 275 :

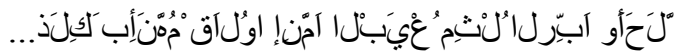

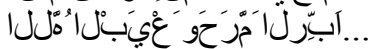

Artinya : Allah menghalalkan jual beli dan mengharamkan riba'.

Dalam ayat ini juga terkandung makna keterkaitan antara sektor riil dengan moneter yaitu jual beli dapat mengaitkan sektor riil (barang) dengan sektor moneter (uang/ harga yang dibayarkan). Senada dengan ayat Al Qur'an diatas, Chapra (2000) menyatakan bahwa Islam tidak memandang segala sesuatu dari segi materiil saja, namun lebih menekankan pada kebahagiaan manusia (falah) dan kehidupan yang baik (hayatan thayyibah) yang sangat menekankan pada aspek persaudaraan (ukhuwah), keadilan sosio-ekonomi dan pemenuhan kebutuhan spiritual umat manusia. Tiga (3) prinsip fundamental dalam Islam yaitu Tauhid (Ke-Esaan), Khilafah (perwakilan), 'adalah (keadilan) yang merupakan bentuk ujung tombak dari terwujudnya maqashid ash-syariah.

Dalam hal strategi pengembangan perbankan syariah dan produk-produknya, pihak perbankan syariah memilih pendekatan yang bertahap dan berkesinambungan (gradual and sustainable) yang sesuai syariah (comply to sharia principles) dan tidak mengadopsi akad-akad yang kontroversial (Ascarya 2006:204-205). Pendekatan yang bertahap dan berkesinambungan memungkinkan perkembangan yang sesuai dengan keadaan dan kesiapan pelaku tanpa dipaksakan serta membentuk sistem yang kokoh dan tidak rapuh. Sementara itu, pendekatan yang berhati-hati yang sesuai dengan prinsip syariah menjamin produk-produk yang ditawarkan terjamin kemurnian syariahnya dan dapat diterima masyarakat luas dan dunia internasional. Senada dengan hal tersebut, perbankan syariah sudah seharusnya memiliki sumber daya manusia (SDM) yang berdaya saing dan handal. Dalam hal ini, perbankan syariah memerlukan SDM yang memiliki dua sisi kemampuan yaitu keterampilan pengelolaan operasional (profesionalism) dan pengetahuan syariah ter- 
masuk akhlak atau moral dengan integritas yang tinggi. Penjabaran lebih lanjut dari SDM perbankan syariah adalah memenuhi persyaratan STAF yang merupakan kependekan dari Shidiq (jujur), Tabligh (membawa dan menyebarluaskan kebaikan), Amanah (dapat dipercaya), dan Fathonah (pandai, memiliki kemampuan). Meninjau praktik bisnis perbankan syariah di Indonesia sendiri sepertinya masih belum mencapai harapan yang semestinya karena masih banyak perbankan yang tidak menghiraukan dua sisi kemampuan sebagaimana penjelasan diatas. Bahkan adanya anggapan masyarakat tentang perbedaan perbankan syariah dengan konvensional dalam hal sumber daya manusia adalah jika di perbankan syariah para karyawannya yang perempuan memakai jilbab dan ketika masuk bank disapa dengan ucapan "Assalamu'alaikum..." Ironis memang jika hal ini tidak diikuti dengan kemampuan (capabilty) dan integritas (integrity) baik spiritual maupun operasional dari sumber daya manusianya.

Salah satu aspek fundamental terkait dengan kemampuan sumber daya perbankan syariah adalah kurangnya pemahaman tentang product knowledge dari perbankan syariah. Product knowledge syariah yang notabene menjadi hal pokok dalam manajemen perbankan syariah yaitu dalam hal pemasaran dan pelayanan kepada nasabah harus menjadi prioritas sebagai upaya memajukan perkembangan perbankan syariah. Berikut ini adalah rangkuman produk-produk dan jasa perbankan syariah:

"Mudarabah: The provision of capital to a partial-equity partnership in return for a share of profits, but where the losses on funds lent are borne by the lender.
Musharakah : Full-equity partnerships where the provider of funds and the entrepreneur directly and wholly share in the business.

Murabaha: An instrument used for financing the purchase of goods and services where the financial institution purchases these on behalf of the customer.

Ba'i Muajjall : Deferred payments on products encompassed under Murabaha.

Ba'i Salam : Advance or prepaid sale contracts of goods and services.

Istisna' : or manufacturing contracts to cover work in progress and paid by the financial institution on behalf of the customer.

Ijarah : lease financing in the form of operating leases only.

Takaful : or Islamic insurance in the form of cooperative self-help schemes.

Quard Hassan : Benevolent loans offered interest free."

(Gait and Worthington 2008)

Sedangkan akad-akad yang dipergunakan oleh perbankan syariah di Indonesia dalam operasinya merupakan akad-akad yang tidak menimbulkan kontroversi yang disepakati oleh sebagian besar ulama dan sudah sesuai dengan ketentuan syariah untuk diterapkan dalam produk dan instrumen keuangan syariah yang ditawarkan kepada nasabah. Untuk mempermudah pengklasifikasian tersebut, maka berikut ini adalah tabel yang menyajikan akad-akad yang digunakan bank syariah di Indonesia.

Tabel 1. Akad-akad perbankan syariah

\begin{tabular}{llll}
\hline \multicolumn{1}{c}{ Akad } & \multicolumn{1}{c}{ Pendanaan } & \multicolumn{1}{c}{ Pembiayaan } & \multicolumn{1}{c}{ Jasa Perbankan } \\
\hline Standar & Wadiah, & Murabahah, Salam, & Wakalah, Kafalah, \\
& Mudharabah & Mudharabah, Istishna, & Hawalah, Rahn, Sharf, \\
& & Musyarakah, Ijarah Muntahiya & Ujr, Mudharabah \\
& & Bittamlik, Qard, Rahn, Hawalah & Muqayyadah \\
Khas & Mudharabah wal Murabahah, & \\
& & Musyarakah wal Murabahah & \\
Kurang Digunakan & Ijarah, Salam, Istishna' & \\
Banyak Digunakan & Murabahah, Mudharabah, & \\
& Musyarakah \\
\hline
\end{tabular}

Sumber : Ascarya 2006:207 
Namun, jika melihat kondisi riil di lapangan, masih terdapat sumber daya perbankan syariah yang belum begitu memahami akan arti pentingnya product knowledge ini sehingga hal ini menyebabkan nasabah menyamakan produk-produk perbankan syariah dengan konvensional. Lebih jauh lagi, kekhawatiran akan terjadinya fenomena lembaga keuangan syariah hanya dijadikan sebuah 'formalitas' demi meraup keuntungan yang sebesar-besarnya sebentar lagi akan terwujud. Inikah yang disebut sebagai Islamic Capitalism ${ }^{5}$ ?

Lembaga-lembaga keuangan syariah terbagi menjadi berbagai macam bentuk dan fungsinya. Ada yang berskala besar (makro) seperi bank syariah, dan ada juga yang berskala kecil (mikro) seperti BPR syariah, koperasi syariah, maupun lembaga mikro keuangan syariah lainnya. Terkait dengan fenomena Islamic Capitalism ini cenderung lebih mengarah pada lembaga mikro syariah dimana pengawasan dari Dewan Syariah $\mathrm{Na}$ sional (DSN) sangatlah kurang. Celah inilah yang biasanya menjadi kesempatan terbuka bagi pelaku usaha mikro syariah untuk "menyelewengkan" esensi dari Maqashid ashSyari'ah (tujuan-tujuan syariah) sebagaimana tercantum dalam Al-Qur'an dan Hadist, dalam konteks ini adalah figh muamalah.

Berdasarkan uraian diatas, maka penelitian ini lebih mengarah pada product knowledge sumber daya dari perbankan syariah sebagai salah satu aspek penting non-material dalam perkembangan bisnis perbankan syariah. Hal ini sesuai dengan pemikiran Gait and Worthington (2008) yang menyatakan bahwa pendirian religius (spiritual) adalah faktor kunci yang digunakan dalam keuangan Islam, disamping itu nasabah juga mempertimbangkan reputasi lembaga perbankan syariah, kualitas pelayanan dan penetapan harga (jual/beli) yang relevan.

Untuk merealisasikan hal tersebut, penulis berusaha menumbuhkan nilai-nilai filosofi dalam dunia pendidikan yaitu trilogi (Ing Ngarsa Sung Tuladha, Ing Madya Mangun Karsa, Tut Wuri Handayani) yang dicetuskan oleh Ki Hadjar Dewantara (KHD) sebagai alat internalisasi kesadaran untuk kembali pada Islam yang kaffah (sempurna/

$5 \quad$ Islam dijadikan 'alat' untuk meneruskan dan memperlancar hegemoni kapitalistik, banyak fakta terselubung dan konspirasi-konspirasi didalamnya sebagai upaya untuk menutupi hal ini. menyeluruh), dan sekaligus menjauhkan praktek perbankan syariah dari pengaruh Islamic Capitalism. Alasan penelitian ini menggunakan filosofi trilogi pendidikan dikarenakan pendidikan itu sejatinya tidak hanya dilakukan dalam ruangan/kelas dimana seorang guru melakukan tranformasi keilmuan kepada peserta didiknya melainkan ketika kita berada pada kondisi dan situasi dalam kehidupan sehari-hari dimana tidak sesuai dengan idealisme yang kita inginkan untuk menciptakan tatanan kehidupan yang sesuai dengan tuntunan Al-Qur'an dan As-sunnah maka kita perlu melakukan pengajaran $^{6}$ di dalamnya sebagai suatu langkah kritis ${ }^{7}$ dalam menjalani setiap proses kehidupan.

Lebih jauh lagi, penulis juga mengimplementasikan nilai-nilai filosofi yang terkandung didalamnya sehingga ketika terjun ke lapangan, penulis bertindak sebagai "guru" dalam memberikan pengertian terkait dengan pemahaman product knowledge lembaga keuangan syariah serta memberikan panutan yang baik (Ing Ngarsa Sung Tuladha). Kemudian ketika penulis tidak sedang berada di lapangan maka proses pendampingan (berupa pemberian motivasi dan ideide yang inovatif) baik dilakukan melalui telepon maupun surat elektonik (Ing Madya Mangun Karsa). Tidak berhenti sampai disitu, ketika penulisan ini sudah selesai pun penulis berusaha tetap memberikan semangat untuk tetap memegang teguh hakikat Maqashid ash-Syariah dalam konteks perbankan syariah (Tut Wuri Handayani). Menurut hemat saya ${ }^{8}$, inilah hakikat filosofi pendidikan yang mencerahkan.

Ketika dikaitkan dengan perspektif Is-

$6 \quad$ Ki Hadjar Dewantara (KHD) mengartikan pengajaran itu tidak lain ialah pendidikan dengan cara memberi ilmu atau pengetahuan serta juga memberi kecakapan pada anak-anak, yang keduanya dapat berfaedah buat hidup anak-anak baik lahir maupun batin (MLPTS (1977) dalam Ekasari 2012).

7 Kritis pada hakikatnya mau menjadi Aufklarung atau pencerahan yang berarti mau membuat cerah, mau menyingkap segala tabir yang menutup kenyataan yang tak manusiawi terhadap kesadaran kita (Magnis dan Suseno 1992:165).

8 Penggunaan kata 'saya' merupakan suatu kesengajaan untuk menekankan penggunaan subyektifitas pada penelitian ini (Kamayanti 2012). 
lam, hal ini bisa dilihat dari pencetus konsep filosofi trilogi pendidikan, Ki Hadjar Dewantara adalah seseorang yang religius ${ }^{9}$ dimana beliau mengaitkan sisi-sisi budaya bangsa Indonesia dengan pendidikan yang religius. Disamping itu, sisi spiritualis beliau terlihat dari pemikiran terkait dengan kemaslahatan seluruh rakyat, lebih jelasnya (penebalan adalah tambahan penulis) :

\begin{abstract}
"Dengan ini kita sudah maju begitu jauh, hingga akan jelas dan terang bagi kita, sebab satu Pengatur Hidup, tanpa ada yang kedua, memegang seluruh pimpinan untuk selamanya dalam tangan-Nya, tidak untuk kepentingan diri, tapi karena cinta kasih terhadap kita, makhluknya, dan untuk ketertiban seluruh hidup."
\end{abstract}

(Ki Hadjar Dewantara 1977:50).

Dengan pendidikan dan pengajaran, beliau bermaksud untuk memerdekakan manusia dari aspek lahir maupun batin yaitu menjadikan seseorang berbudi luhur yang terbebas dari kebodohan dan kemiskinan (Ekasari 2012:5). Dalam hal ini sangat terlihat bahwa beliau tidak hanya mengedepankan aspek materiil, namun aspek spiritual juga menjadi pokok penting dalam proses pendidikan dan pengajaran. Ajaran inilah yang sesuai dengan hakikat Islam yang tidak hanya mengejar kebahagiaan dunia (hubbud dunya') namun juga harus memikirkan kehidupan akhirat. Sebagai justifikasi akan hal ini, Fontaine (2008) juga menyebutkan bahwa nasehat sering diterjemahkan sebagai "memberikan pemahaman yang tulus" namun kata itu berarti jauh lebih baik daripada hanya memberikan saran. Hal ini mencakup pengertian tentang membantu orang lain dengan cara apapun.

Berdasarkan uraian-uraian di atas, dapat diambil sebuah benang merah bahwa selama ini banyak yang memandang sebelah mata akan arti pentingnya sebuah lembaga keuangan yang "murni" syariah. Selain itu, fenomena yang berkembang di masyarakat bahwa lembaga keuangan syariah tidak terdapat perbedaan yang signifikan jika dibandingkan dengan lembaga keuangan konvensional, hal ini ditambah dengan perilaku

9 Lihat Karja Ki Hadjar Dewantara, bagian IIA: Kebudajaan. 1967. Bab Islam dan Kebudajaan halaman 52. Madjlis Luhur Persatuan Taman Siswa (MLPTS) Yogyakarta. beberapa oknum perbankan syariah yang sengaja menambahkan "embel-embel" syariah sebagai "daya tarik" untuk mengeruk keuntungan (profit) semata. Maka dari itu, penulis mencoba fokus untuk memberikan pemahaman sumber daya perbankan syariah terkait dengan product knowledge yang semestinya menjadi hal pokok untuk dimengerti oleh para pelaku perbankan syariah sehingga pada saat melayani nasabah tidak terjebak dalam produk perbankan konvensional. Dengan demikian, tujuan penelitian ini adalah untuk mengimplementasikan nilai-nilai filosofis trilogi pendidikan Ki Hadjar Dewantara dalam membangkitkan kesadaran akan arti pentingnya product know-ledge sebagai salah satu aspek nonmaterial dalam perbankan syariah.

\section{METODE}

Sejatinya, sebuah kutipan tentang harapan dari salah satu pejuang kemerdekaan negara kita, yaitu Ki Hadjar Dewantara yang saya cantumkan di awal artikel ini, sangatlah mempunyai makna yang dalam dimana kita sebagai rakyat Indonesia harus selalu mempunyai pemikiran yang kritis terhadap segala kondisi yang ada di sekitar kita. Setiap bentuk penindasan dan penjajahan baik itu secara eksplisit maupun implisit terhadap segala aspek kehidupan haruslah diperjuangkan agar kita menjadi manusia yang terbebaskan, tanpa "genggaman" dari pihak-pihak lain yang berkepentingan. Lebih lanjut, cerminan semangat kemandirian dan kemerdekaan terdapat dalam kutipan berikut ini.

"Dari kodratnja, sebagai makhluk yang ber-trimurti, manusia mempunjai kesanggupan serta kemampuan untuk berdjoang dan membangun. Menginsafi kenjataan ini selandjutnja adalah perlu, karena keadaan hidup dan penghidupan kita hingga sekarang, kadang-kadang memberi kesan sebaliknja. Seolah-olah bangsa kita - lebih tegas para pemimpinpemimpinnja - banjak jang melupakan akan keharusan manusia untuk berdjoang dan membangun, terus menerus selama ia hidup."

(Ki Hadjar Dewantara 1967:92-93, ejaan dan garis miring sesuai teks aslinya) 
Terkait dengan hal ini, pendidikan dapat diartikan sebagai salah satu usaha untuk menuju kepada peradaban yang adil dan sejahtera, membebaskan dari kemiskinan dan kebodohan.

Dalam konteks penelitian ini, pengajaran dan pendidikan dijadikan metode untuk memberikan pemahaman tentang product knowledge dalam perbankan syariah. Pentingnya moral dan etika juga menjadi poin penting dalam proses internalisasi nilai-nilai trilogi pendidikan KHD agar para pelaku perbankan syariah dalam menjalankan usahanya tidak hanya memikirkan aspek materiil namun juga spiritual. Hal ini sesuai dengan pemikiran Ron Miller yang dikenal sebagai bapak Pendidikan Holistik di Amerika yang menyatakan bahwa pendidikan harus mengandung nilai moral, sosial dan menciptakan manusia yang utuh (Ekasari 2012:55). Terkait dengan pemikiran ini, KHD dalam bukunya yang berjudul Pendidikan (1977:48) menyatakan bahwa :
"Alat pendidikan yang memelihara dengan sebesar perhatian untuk mendapat tumbuhnya hidup anak, lahir dan batin menurut kodratnya sendiri, inilah yang disebut Among-Methode. Dalam sistem ini maka pengajaran berarti mendidik anak akan menjadi manusia yang merdeka batinnya, merdeka fikirannya dan merdeka tenaga-nya. Guru jangan hanya memberi pengetahuan yang perlu dan baik saja, akan tetapi harus juga mendidik si murid akan dapat mencari sendiri pengetahuan itu dan memakainya guna amal keperluan umum."

Pernyataan inilah yang mendasari pemikiran saya bahwa pendidikan dan pengajaran mempunyai makna yang lebih luas dan tidak hanya dimaknai sebagai proses belajar-mengajar yang terjadi di dalam kelas seperti layaknya pendidikan saat ini.

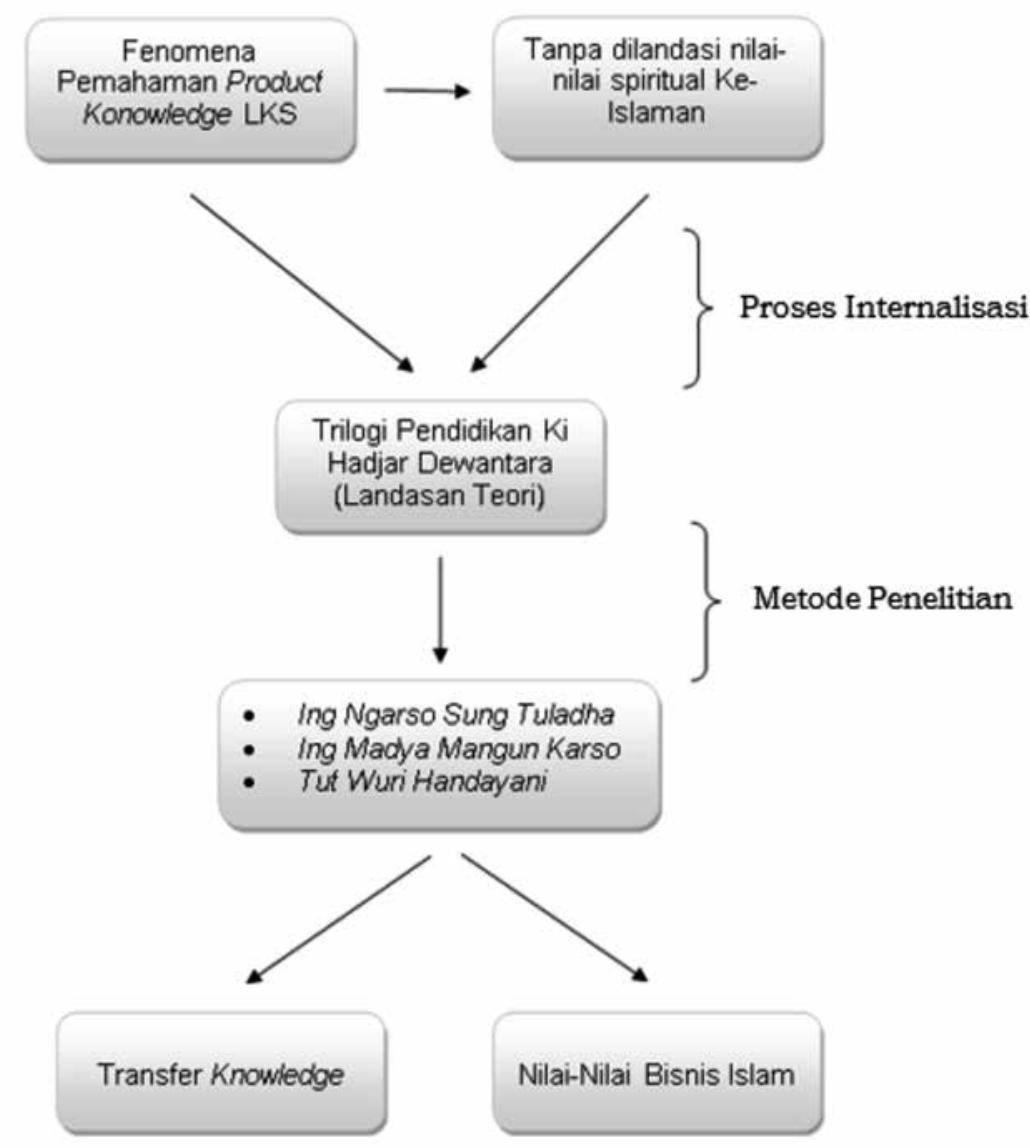

Gambar 1. Rerangka Konseptual Penelitian 


\section{Trilogi Pendidikan Ki Hadjar Dewantara}

Ing Ngarsa Sung Tuladha secara harfiyah berarti bahwa seseorang (dalam hal ini penulis) yang berada di depan hendaknya memberikan contoh yang baik. Sung berasal dari kata asung yang dalam bahasa Jawa berarti memberi. Dalam kalimat tersebut, Ki Hadjar Dewantara berpesan agar sung itu diartikan menjadi. Karena antara memberi dan menjadi mempunyai makna yang berbeda (Ki Suratman 1990:22). Jadi dalam falsafah ini, penulis berusaha menjadi "guru" yang dapat menjadi suri tauladan bagi manajer dan karyawan usaha jasa keuangan syariah "Surya" dalam menjalankan roda manajemen usaha tersebut, dimana product knowledge haruslah dijelaskan kepada nasabah sesuai dengan arti yang sesungguhnya tanpa adanya motif-motif yang menginginkan maksimalisasi keuntungan. Etika dan moral dalam menyampaikan penjelasan juga menjadi faktor penting yang turut diperhatikan.

Ing Madya artinya di tengah-tengah, Mangun berarti membangkitan atau menggugah dan Karsa diartikan sebagai bentuk kemauan atau niat. Makna dari Ing Madya Mangun Karsa adalah seseorang ditengah kesibukan aktivitasnya harus juga mampu membangkitkan atau menggugah semangat orang lain (Ki Suratman 1990:22). Jadi dalam falsafah yang kedua ini mengandung pengertian bahwa seorang penulis, jika ditengah-tengah informan penelitian harus mampu memberikan motivasi agar bisa mempersatukan semua gerak dan perilaku secara serentak untuk mencapai tujuan bersama. Dari falsafah yang kedua ini dapat dilihat makna kebersamaan, kekompakan dan kerjasama dalam suatu organisasi atau perusahaan.

Tut Wuri artinya mengikuti dari belakang dan Handayani berarti memberikan dorongan moral atau dorongan semangat. Jika digabung maka artinya Tut Wuri Handayani ialah seseorang harus memberikan dorongan moral dan semangat kerja dari belakang (Ki Suratman 1990:22). Jadi dalam falsafah yang ketiga ini, penulis berusaha memberikan dorongan motivasi dan bantuan terkait dengan setiap permasalahan yang terjadi pada unit jasa keuangan syariah "Surya" walaupun ketika penelitian ini berakhir akan tetap memberikan penjelasan dan pemahaman tentang product knowledge perbankan syariah jika memang masih terdapat permasalahan.
Berikut ini adalah gambar rerangka penelitian yang dijadikan acuan dalam proses implementasi filosofi trilogi pendidikan Ki Hadjar Dewantara.

Secara teknis, penulis perlu melakukan intervensi dalam kaitannya dengan implementasi nilai-nilai filosofi trilogi Ki Hadjar Dewantara. Kamayanti et al. $(2011)^{10}$ menyatakan bahwa intervensi sangat unik dengan tak terbatas variasi serta sangat kontekstual. Hal ini memberikan kemajuan pengetahuan tentang perubahan yang bekerja dalam sebuah organisasi. Dari pernyataan ini penulis dapat memahami bahwa suatu perubahan yang dapat menimbulkan kesadaran bagi objek penelitian terkait dengan suatu kebenaran akan terjadi jika penulis melakukan intervensi baik di wilayah pemikiran maupun praktiknya.

Lebih jauh tentang hakikat intervensi, Jonsson (2010) menyatakan dalam aspek intervensionisme ilmu sosial, kita tidak bisa mengabaikan fakta bahwa suatu penelitian memiliki pengaruh terhadap objek penelitian. Berikut ini adalah hal-hal menarik yang perlu diperhatikan terkait dengan penelitian intervensionisme, antara lain:

"The fact that interventions include learning (and therefore the researcher needs to be concerned with context and "site"); The fact that interventions normally are unique (Look! A generalization!); The fact that interventions have effects over time (including continuous learning and probably no equilibrium that marks the end of the intervention); And all of which points to the need to report interventionist research as case narratives, and to the need to develop adequate data capture methods" (Jonsson 2010).

Salah satu argumen dalam pendekatan intervensionisme adalah penulis harus memiliki landasan teori yang dapat dipercayai akan bekerja dalam praktiknya (Jonsson 2010). Intinya disini adalah intervensi penulis ke dalam suatu penelitian membutuhkan teori tentang bagaimana praktik tersebut dapat dimplementasikan sesuai dengan tujuan penelitian. Jika dikaitkan dengan pene-

10 Kamayanti, A., Gugus I., Aulia Fuad R. 2011. Dramaturgical Interventionism Approach in Accounting Education Research. 
litian ini, maka hal ini menjadi argumen saya mengapa menggunakan filosofi trilogi pendidikan Ki Hadjar Dewantara dengan metode praktiknya yaitu Ing Ngarsa Sung Tuladha, Ing Madya Mangun Karsa, Tut Wuri Handayani.

Situs pada penelitian ini adalah usaha jasa keuangan syariah "Surya" yang bertempat di Jl. Seruji 15 Gurah Kabupaten Kediri. Unit jasa keuangan syariah ini merupakan salah satu bagian unit usaha dari Koperasi Serba Usaha "Surya" yang terletak di Jl. Gajahmada No. 88 Kwadungan, Ngasem, Kabupaten Kediri. Selain memiliki unit jasa keuangan syariah, koperasi ini juga memiliki beberapa unit usaha yang lainnya yaitu gudang distributor, grosir dan swalayan yang tersebar di kota Kediri dan sekitarnya.

Dalam hal pengumpulan data, penulis merujuk pada strategi pengumpulan data kualitatif yang dijelaskan oleh Creswell (2012:267-270) bahwa metode pengumpulan data dibagi menjadi empat jenis, antara lain: (1) Observasi, yaitu kunjungan langsung ke lapangan untuk mengamati perilaku dan kegiatan individu-individu di lokasi penelitian. (2) Wawancara, terdiri dari wawancara tatap muka (langsung), lewat telepon, atau dalam sebuah diskusi via media sosial. (3) Dokumentasi, dapat berupa dokumen publik seperti majalah, makalah, dan laporan kantor ataupun dokumen pribadi seperti buku harian, surat, ataupun email, dan terakhir, (4) Rekaman suara dan gambar, seperti foto, objek seni, video, dan segala jenis bunyi/suara lainnya.

Lebih lanjut, Jonsson (2010) menyatakan bahwa wawancara akan menjadi sumber data penting, dan penulis harus menyertakan pertanyaan terbuka untuk memungkinkan pengamatan dan penemuannya sendiri. Maka dari itu, dalam penelitian ini akan disajikan rekaman hasil wawancara dengan informan untuk mengetahui perubahan pola pikir yang diinginkan dalam penelitian ini. Selain itu juga akan penulis sajikan cuplikan diskusi dari media sosial terkait dengan topik penelitian ini.

\section{HASIL DAN PEMBAHASAN}

Secara umum, penulis telah terjun ke lapangan guna pengambilan data melalui wawancara sebanyak tiga kali, yaitu pertama, tanggal 28 September 2013, kedua, pada tanggal 14 Oktober 2013, dan yang terakhir tanggal 24 Desember 2013. Wawancara dilakukan kepada saudara RM selaku general manajer unit jasa keuangan syariah "Surya" dan juga kedua teller yang bekerja di unit usaha ini (LS dan NV). Namun disini, penulis lebih memprioritaskan kepada saudara RM sebagai pemimpin dan juga pengambil kebijakan, maka dari itu jika penelitian ini berhasil membawa dampak perubahan pemikiran baginya, berarti secara normatif seluruh stakeholder dalam unit jasa keuangan syariah ini juga berpotensi ikut berubah, tentunya kearah yang lebih ideal. Senada dengan hal ini, Jonsson (2010) menyatakan bahwa inti dari manajemen adalah intervensi, dimana penulis mengartikan manajemen disini lebih mengarah kepada pemimpin dalam organisasi bisnis tersebut. Jadi begitu penting peran dari pemimpin untuk mengintervensi rekan-rekan kerjanya dalam sebuah unit bisnis syariah.

Dalam wawancara pertama, penulis berusaha menggali permasalahan-permasalahan apa yang sedang dihadapi oleh unit usaha ini selama menjalankan roda organisasinya. Selain itu, penulis juga berusaha mencari tahu akan sejarah, proses pendangan sampai penyalurannya kepada nasabah di unit jasa keuangan syariah ini. Dari sinilah kenapa penulis memutuskan mengambil topik pemahaman product knowledge yang masih kurang baik, sehingga disini penulis berusaha untuk menginternalisasikan nilai-nilai trilogi pendidikan Ki Hadjar Dewantara untuk memberikan pemahaman product knowledge beserta nilai ketauhidan yang menyatu di dalamnya. Wawancara kedua lebih diarahkan kepada proses internalisasi tersebut sehingga diskusi yang kami lakukan merupakan wujud dari transfer knowledge dari penulis kepada saudara RM. Sedangkan wawancara ketiga, penulis lebih melihat kepada sejauh mana dampak intervensi yang telah dilakukan kepada pola pemikiran saudara RM. Disini penulis juga akan memberikan bukti-bukti yang menunjukkan adanya perubahan pemikiran terkait dengan arti penting product knowledge beserta nilai-nilai Islam yang seharusnya mendasari terbentuknya unit bisnis perbankan syariah, yaitu melalui percakapan via media sosial.

Pada dasarnya, seperti yang telah diungkapkan saudara RM bahwa cikal bakal berdirinya unit jasa keuangan syariah "Surya" dengan tujuan untuk memenuhi kebutuhan financial para karyawan di unit bisnis yang lain, seperti grosir, swalayan dan juga gudang distributor. Jadi bisa dikatakan 
bahwa sebagian besar nasabahnya adalah para pegawai lain yang masih bekerja pada payung koperasi induk "Surya". Hal ini dikarenakan sebagian besar karyawan tersebut mempunyai penghasilan di bawah UMR kabupaten Kediri, yaitu kurang dari satu juta rupiah. Sehingga dengan adanya unit jasa keuangan syariah ini dapat memudahkan para karyawan tersebut jika membutuhkan bantuan financial. Namun disini penulis melihat adanya fenomena karyawan yang "tereksploitasi" yaitu dengan adanya peraturan yang mewajibkan untuk melakukan transaksi simpan-pinjam di unit usaha jasa syariah ini, akan tetapi saudara RM melihat hal ini sebagai hal yang wajar dan sah-sah saja menurut hukum perbankan Islam. Berikut ini kutipan wawancaranya:

\begin{abstract}
"Ya, saya melihat sistem seperti ini adalah hal yang wajar dan tidak melanggar hukum baik Islam maupun negara. Coba lihat bank Sinarmas yang notabene kurang terkenal di kalangan masyarakat namun tetap saja bisa bertahan sampai sekarang karena sebagian besar nasabahnya adalah para karyawan dari unit usaha yang lain milik PT. Sinarmas Group."
\end{abstract}

Terkait dengan bidang usahanya dalam bisnis syariah, maka unit usaha ini juga melakukan setiap aktivitas bisnisnya dengan berdo'a bersama setiap hari sebelum pekerjaan dimulai. Hal ini dimaksudkan untuk menciptakan lingkungan kerja yang spiritualis dan sesuai dengan tuntunan syariah. Sedangkan dalam transaksi yang terkait dengan pinjaman nasabah, maka unit usaha ini juga memperlakukan nasabah yang belum bisa membayar secara tepat waktu untuk mengangsur dengan penjadwalan kembali (restrukturisasi) ataupun dilakukan penagihan dengan cara-cara yang syariah, tanpa mendzolimi orang lain, bahkan dido'akan agar segera mendapatkan rezeki yang barakah. Mengenai zakat yang telah dimasukkan ke dalam potongan pembayaran angsuran juga dikumpulkan setiap bulan untuk kemudian disalurkan kepada pihak yang membutuhkan, sehingga peran unit jasa keuangan syariah ini tidak hanya dalam aspek ekonomi, namun juga sosial dan agama.

Namun disini ada beberapa hal yang penulis rasakan bertolak belakang (kontradiktif) dengan hal-hal diatas yaitu ke- tika saudara RM mengatakan bahwa sebagian besar dana yang didapatkan untuk memenuhi kebutuhan para nasabah berasal dari pinjaman juga dari salah satu bank konvensional di kota Kediri, yang notabene pasti memakai sistem bunga (riba). Seharusnya jika induk unit bisnis ini adalah koperasi, maka dana yang diputar adalah dari anggota dan untuk anggota. Namun kenyataan dalam praktiknya tidaklah demikian, karena minimnya jumlah anggota yang menabung, maka pemilik mengambil jalan pintas untuk mendapatkan dana "segar" dari pihak ketiga yaitu pinjaman bank konvensional tersebut.

Jadi, ketika penulis menyimpulkan aktivitas bisnis yang dilakukan di unit jasa keuangan syariah ini secara tekstual memang sesuai dengan prinsip-prinsip syariah, namun secara kontekstual masih belum dikatakan murni syariah, hal ini sesuai dengan apa yang dikatakan oleh kedua teller (LS dan NV) yang saya wawancarai sebagai berikut.

S : "Apakah menurut anda unit jasa keuangan syariah ini sudah sesuai dengan prinsip-prinsip syariah?"

LS : "Ehmm, menurut saya kok belum ya, karena biasanya kalau yang benar-benar syariah itu ketika akan pencairan dana akan berdo'a, tetapi disini tidak, langsung begitu saja. Disini juga lebih banyak produknya itu adalah pembiayaan, sangat mirip dengan lembaga konvensional dengan simpan-pinjamnya, atau fundinglending. Sama bagi hasilnya disini ditentukan di awal oleh pihak sini, bukan berdasarkan kesepakatan antara kedua belah pihak."

$\mathrm{S}$ : "Kalau menurut anda mbak NV?"

NV : "Pada dasarnya sama antara aktivitas yang disini dengan yang dikonvensional, cuma disini ditambahi dengan akad syariah gitu. Toh, masyarakat pun (nasabah) juga tidak terlalu mempermasalahkan hal ini $k o k$, yang penting sama-sama membantu."

Dari beberapa hasil wawancara diatas menunjukkan bahwa memang benar anggapan banyak masyarakat bahwa secara detail, 
masih belum ada perbedaan yang signifikan antara unit jasa keuangan syariah dengan konvensional. Perbedaannya hanyalah nama akad ketika akan bertransaksi di awal kontrak. Dan juga dalam unit usaha syariah ini sebagian besar nasabahnya melakukan akad pinjaman seperti halnya kredit yang ada di lembaga keuangan konvensional. Product knowledge para pelaku bisnis keuangan syariah ini juga kurang baik, karena bagi mereka produk pembiayaan murabahah, mudharabah, dan musyarakah hampir sama dengan yang mereka lakukan saat ini, yaitu intinya pinjaman. Padahal jika kita mengacu pada ilmu figh muamalah, terdapat ciri khas diantara akad-akad pembiayaan tersebut dan tidak bisa untuk disamakan sedemikian rupa.

Seperti penjelasan di awal penelitian bahwa penulis disini ketika terjun ke lapangan memposisikan diri sebagai "guru" dalam memberikan pemahaman terkait dengan arti penting product knowledge bagi unit usaha jasa keuangan syariah ini. Proses intervensi dalam memberikan kesadaran melalui diskusi baik itu secara langsung maupun melalui media sosial memberikan dampak yang cukup signifikan, yaitu adanya pengakuan dari saudara RM sebagai berikut.

"Ya, memang lembaga ini masih belum murni sesuai dengan prinsip-prinsip syariah, terutama dalam produk-produknya, juga sistemnya, namun saya berusaha untuk mengarah kesana dan terimakasih anda telah memberikan wawasan yang baru bagi saya".

Dari kesadaran ini, penulis mulai untuk memberikan perubahan pemikiran dari pemimpin unit jasa keuangan syariah ini agar mengarahkan produk-produk syariahnya sesuai dengan kaidah figh muamalah yang berlaku, walaupun tidak bisa secara langsung, namun harus secara berkelanjutan untuk proses pendampingan. Akad pembiayaan murabahah misalnya, seharusnya barang yang akan diperjual belikan itu sudah dibeli oleh pihak lembaga keuangan syariah, namun di unit bisnis ini yang terjadi adalah nasabah diminta untuk membeli sendiri dengan uang pembiayaan dari lembaga keuangan syariah. Hal ini menunjukan bahwa meskipun murabahah dipermukaan tampak sebagai kontrak jual beli, namun ia adalah suatu jenis pembiayaan berdasarkan keuntungan yang ditetapkan dimuka yang tidak jauh berbeda dengan pembiayaan berdasarkan bunga tetap. Bahkan banyak pakar kritis perbankan syariah mengatakan bahwa untuk tujuan praktis sistem mark up dalam murabahah ini akan sama baiknya bagi LKS untuk memberikan pinjaman berdasarkan suku bunga tetap saja. Karena jika bunga secara luas diganti dengan mark up, maka ia mencerminkan hanya perubahan nama ketimbang substansinya.

Disini penulis juga menggarisbawahi ketika sudah dikemukakan di awal bahwa unit jasa keuangan syariah ini juga meliputi fungsi sosial dan agama, disamping fungsi ekonomi tentunya, namun pada sesi wawancara ketiga, dengan jelas saudara RM mengatakan bahwa lembaga bisnis ini tetap berfokus pada keuntungan (profit oriented) dimana fungsi ekonomi lebih dikedepankan dari pada fungsi sosial dan agama. Sehingga pengarahan untuk menjadi lembaga syariah yang idealis memang tidaklah mudah karena pemikiran pemimpinnya saja sudah mendarah daging dengan ajaran kapitalis.

Makna yang terkandung dalam trilogi yang kedua adalah jika seseorang ditengah kesibukan aktivitasnya harus juga mampu membangkitkan atau menggugah semangat orang lain. Disini penulis menganalogikan bahwa intervensi yang dilakukan sebagai peneliti untuk memberikan motivasi kepada saudara RM agar tetap berjalan pada "koridor" syariah yang ideal sehingga arah perjalanan unit jasa keuangan syariah ini tetap diridhoi Allah SWT. Bentuk pemberian semangat ini dapat berupa perhatian terhadap jalannya unit jasa keuangan syariah ini apakah sudah ada perubahan agar menjadi lembaga keuangan syariah yang ideal menurut figh dan ajaran Islam.

Internalisasi nilai tersebut dibuktikan dengan beberapa bentuk diskusi melalui media sosial antara penulis dengan saudara RM berikut ini.

Dalam hal ini, penulis melihat bahwa sulitnya melakukan perubahan ke arah yang lebih idealis, tidak sebatas pada hal-hal yang pragmatis. Karena sepengetahuan saya selama proses penelitian, produk-produk syariah yang pragmatis saja sudah dipahami sebagai sesuatu yang idealis bagi mereka, jadi memang perlu pendekatan yang lebih eksklusif dan juga waktu yang lebih panjang agar tercipta kondisi yang idealis sepenuhnya. Maka dari itu, hal ini juga menjustifikasi kenapa saya menggunakan metode penelitian ini. 


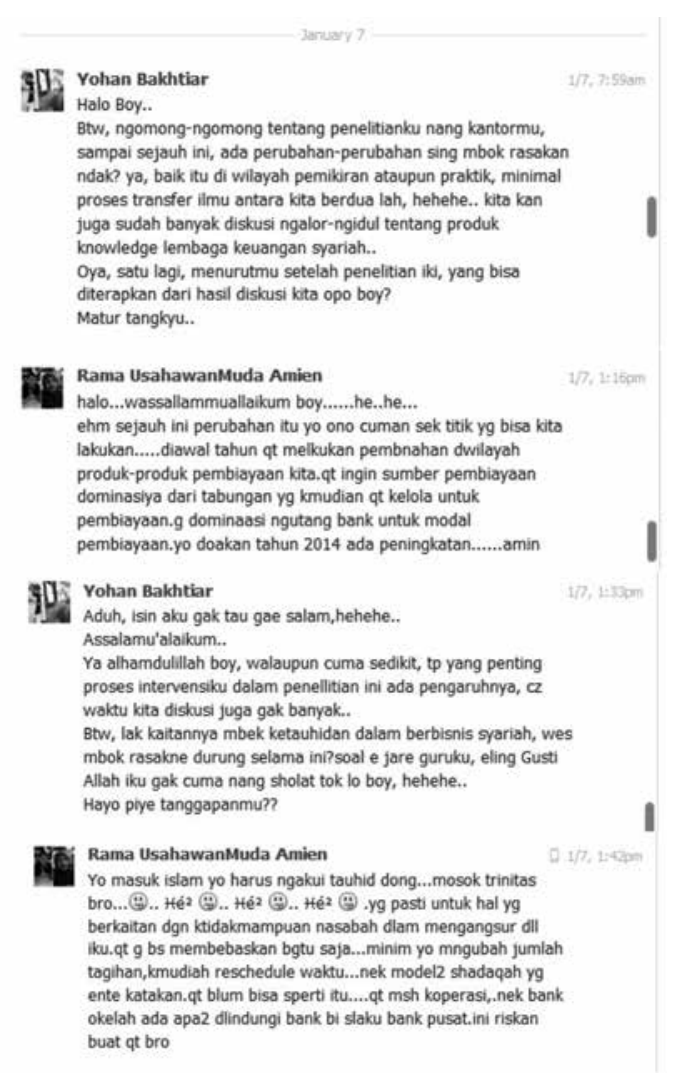

Makna dari trilogi yang ketiga yaitu seseorang harus memberikan dorongan moral dan semangat kerja dari belakang ketika tidak bisa intens mendampingi pada waktu penelitian. Jadi penulis juga memberikan perhatian secara continue agar keberhasilan penelitian dalam memberikan kesadaran dan perubahan terhadap pemikiran general manager unit usaha keuangan syariah ini dapat berjalan sesuai dengan prinsip Islam. Pun juga ketika penelitian ini sudah berakhir, maka saya sebagai peneliti yang bertanggung jawab akan tetap mendampingi dan memberikan motivasi ketika terdapat permasalahan terkait dengan product knowledge. Berikut ini bukti konkrit diskusi yang mengarah pada makna ketiga ini.

\section{SIMPULAN}

Dari rangkaian proses penelitian ini dapat disimpulkan bahwa trilogi pendidikan Ki Hadjar Dewantara dapat menjadi sebuah alat internalisasi dalam menyampaikan pemahaman terkait dengan product knowledge pada unit jasa keuangan syariah "Surya". Penulis juga melakukan intervensi sebagai salah satu tujuan untuk memberikan kesadaran dan perubahan terhadap nilai-nilai bisnis keuangan Islam yang semula dipersamakan dengan bisnis keuangan kon-

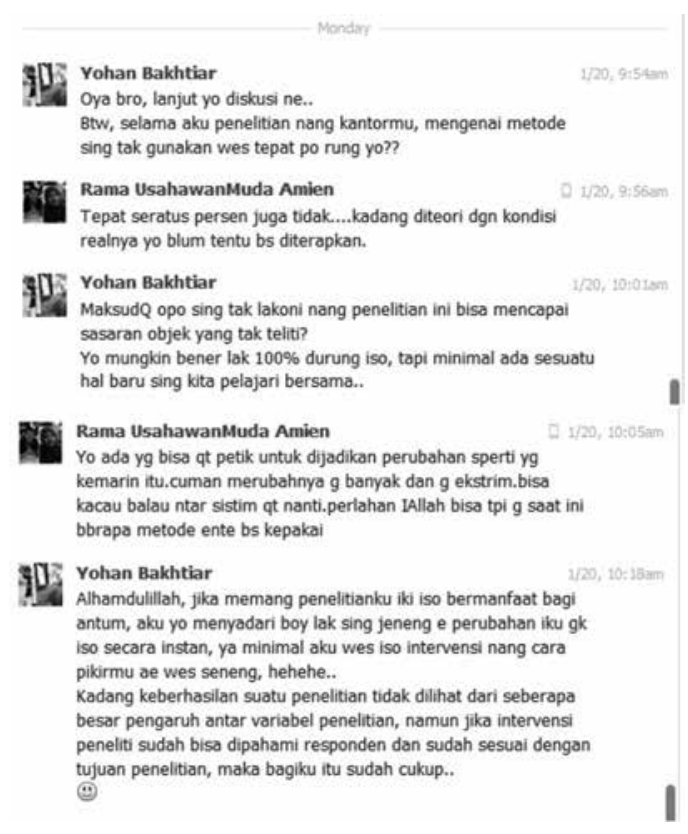

vensional, sehingga perubahan kepada bisnis keuangan Islam yang ideal dapat terwujud. Walaupun demikian, perubahan yang terjadi tidak serta merta secara signifikan, melainkan selangkah demi selangkah agar dapat terlaksana dengan baik. Maka dari itu, proses pendampingan sangat mutlak dilakukan dalam penelitian ini. Hal inilah yang menjustifikasi kenapa saya memilih metode Ing Ngarsa Sung Tuladha, Ing Madya Mangun Karsa dan Tut Wuri Handayani.

Beberapa keterbatasan dalam penelitian ini adalah sedikitnya literatur penelitian terdahulu yang terkait dengan kurangnya pemahaman product knowledge dalam lembaga bisnis syariah, penulis sudah berusaha untuk mencari di jurnal internasional maupun nasional tetapi belum menemukan yang sesuai dengan konteks ini. Kebanyakan penelitian tersebut membahas mengenai pembiyaan murabahah, mudharabah dan musyarakah. Selain itu, penggalian makna Ing Ngarsa Sung Tuladha, Ing Madya Mangun Karsa dan Tut Wuri Handayani seharusnya selain dari literatur buku maupun jurnal ilmiah, juga dilakukan melalui wawancara dengan beberapa orang di perguruan Taman Siswa Yogyakarta (MLTS), namun karena keterbatasan waktu, sehingga hal ini belum terlaksana dengan baik. 


\section{DAFTAR RUJUKAN}

Al Qur'an dan terjemahan (digital) versi 2.1, Software Computer. http://www. alquran-digi tal.com

Ascarya. 2006. Akad dan Produk Bank Syariah : Konsep dan Praktik di Beberapa Negara. Bank Indonesia. Agustus 2006. Jakarta.

Capra, M., Umer. 2000. Islam and Economic Challenge. Ikhwan Abidin Basri (penerjemah). Islam dan Tantangan Ekonomi. Gema Insani Press. Jakarta.

Creswell, J. W. 2012. Research Design: Qualitative, Quantitative, and Mix Methods Approaches Third Edition. Achmad Fawaid (penerjemah). Reseach Design: Pendekatan Kualitatif, Kuantitatif dan Mixed. Pustaka Pelajar: Yogyakarta.

Dewantara, Ki Hajar. 1967. Bagian IIA : Kabudajaan. Diterbitkan oleh MadjelisLuhur Persatuan Taman Siswa. Ditjetak oleh Pertjetakan Taman Siswa. Jogjakarta.

Dewantara, Ki Hajar. 1977. Bagian I : Pendidikan. Cetakan kedua. Diterbitkan oleh Madjelis-Luhur Persatuan Taman Siswa. Jogjakarta.

Ekasari, K. 2012. [Re]Konstruksi Pendidikan Akuntansi di Tingkat Pendidikan Vokasi, Melalui Epistimologi 3ling. Disertasi tidak diterbitkan. Fakultas Ekonomi dan Bisnis Universitas Brawijaya.

Fontaine, Rodrigue. 2008. Problem Solving: an Islamic Management Approach. Cross Cultural Management: An International Journal. Vol. 15, No. 3, hlm 264274.

Gait, A. and A. Worthington. 2008. An Empirical Survey of Individual Consumer, Business Firm and Financial Institution Attitudes Towards Islamic Meth- ods of Finance. International Journal of Social Economics. Vol. 35, No. 11, hlm 783-808.

Jonsson, Sten. 2010. Interventionism - an approach for the future?. Qualitative Research in Accounting and Management. Vol. 7, No. $1 \mathrm{hlm}$ 124-134.

Kamayanti, Ari. 2012. Cinta: Tindakan Berkesadaran Akuntan (Pendekatan Dialogis dalam Pendidikan Akuntansi). Simposium Nasional Akuntansi (SNA) XV Banjarmasin, 20-23 September.

Kamayanti, A., Gugus I., Aulia Fuad R. 2011. Dramaturgical Interventionism Approach in Accounting Education Research. The $6^{\text {th }}$ Qualitative Research Convention Malaysia, 13-15 November.

Khobir, Abdul. 2010. Islam dan Kapitalisme. Jurnal Religia. Vol. 13, No. 2. hlm 225238

Ki Suratman. 1990. Kepemimpinan Ki Hajar Dewantara dan Penerapan Sistem Among, MLPTS. Yogyakarta.

Mackey, John. 2007. Conscious Capitalism: Creating a New Paradigm for Business. CEO, Whole Foods Market, co-founder, FLOW.

Magnis, F., dan Suseno. 1992. Filsafat sebagai Ilmu Kritis. Penerbit Kanisius. Yogyakarta.

Saifullah, Muhammad. 2011. Etika Bisnis Islami dalam Praktek Bisnis Rasulullah. IAIN Walisongo Semarang, Vol. 19, No. 1

Shonhadji, Nanang. 2013. Hegemoni "IFRS" pada Praktik Akuntansi Perbankan di Indonesia, Tinjauan Pemikiran Kritis Gramsci. Makalah I Disertasi Pascasarjana Fakultas Ekonomi dan Bisnis Universitas Brawijaya. 